\title{
Magical science sebagai media pembelajaran IPA berbasis website untuk siswa tunarungu
}

\author{
Indina Tarjiah $^{1}$, Erfan Kurniawan ${ }^{2}$, Riana Bagaskorowati ${ }^{3}$ \\ ${ }^{1,2,3}$ Program Studi Pendidikan Khusus, Fakultas Ilmu Pendidikan, Universitas Negeri Jakarta, 13220 \\ *Corresponding Author. E-mail: indina.tarjiah@gmail.com, erfan.kurniawan25@gmail.com, \\ riana.bagaskorowati@unj.ac.id
}

\begin{abstract}
Abstrak: Penelitian ini bertujuan untuk menghasilkan produk berupa media magical science untuk memvisualisasikan daur hidup hewan kupu-kupu dalam bentuk 3D bagi siswa tunarungu. Media ini menggunakan metode research and development $(\mathrm{RnD})$ dengan model pengembangan Sugiyono yang meliputi tahap potensi dan masalah, pengumpulan data, desain produk, validasi desain, revisi desain, uji coba produk, dan revisi produk. Validasi dilakukan oleh tiga ahli yaitu ahli media, ahli tunarungu, dan ahli materi dengan hasil rata-rata keseluruhan yang telah dicapai adalah baik, yaitu dengan nilai 3,36 dari nilai maksimal 4. Media magical science diujicobakan kepada enam siswa kelas V di SLB Negeri 4 Jakarta. Hasil penelitian ini menunjukkan bahwa hasil belajar siswa dari pre test dan post test mengalami peningkatan yang cukup signifikan, sehingga media magical science dapat digunakan untuk memvisualisasikan daur hidup hewan kupukupu dalam bentuk 3D. Diharapkan guru dapat menggunakan media magical science pada pembelajaran IPA lainnya.
\end{abstract}

Kata Kunci: pembelajaran IPA, media magical science, siswa tunarungu

\section{Magical science as instruction media of subject matter science (IPA) for hearing impairment student}

\begin{abstract}
This research intends to produce a learning media to visualize the life cycle of butterfly in 3D for deaf students which is magical science. This media uses research and development (RnD) method according to Sugiyono's model development that comprise process: problems and potentials, data collection, product design, design validation, design revision, product testing, and product revision. The validation is conducted by three experts, they are expert of media, expert of deaf, and expert of material. The overall validation result is satisfied with score 3,36 out of 4. Magical Science media is tested to six fifth-grade students in SLB Negeri 4 Jakarta. The findings suggest that students studies from pre test and post test are increasing significantly, so Magical Science can be used to visualize the life cycles of butterfly animals in 3D. It is hoped that teachers use magical science in the science learning.
\end{abstract}

Keywords: science learning, magical science media, deaf students

\section{PENDAHULUAN}

IPA merupakan ilmu yang mempelajari tentang gejala-gejala alam dan kebendaan yang sistematis, tersusun secara teratur, berlaku secara umum, berupa kumpulan hasil observasi dan eksperimen (Nana Djumhana, 2009:2). Pembelajaran IPA dibagi menjadi tiga yaitu fisika, kimia, dan biologi (Maskoeri Jasin, 2008:36-38). Pembelajaran IPA tidak hanya dilakukan oleh siswa pada umumnya saja. Siswa berkebutuhan khusus juga perlu belajar IPA, salah satunya siswa tunarungu. Tunarungu adalah gangguan pendengaran yang bersifat permanen atau sementara yang mempengaruhi kinerja pendidikan anak (Roger Pierangelo dan George Giuliani, 2006:145). Kehilangan pendengaran berpengaruh pada perkembangan fungsi kognitifnya, karena anak tunarungu mengalami kesulitan dalam memahami informasi yang bersifat verbal terutama pada hal yang abstrak (Rochman Natawidjaya dan Zainal Alimin, 1996:126). Selain itu, kehilangan pendengaran menyebabkan hambatan pada komunikasi. Komunikasi merupakan faktor penting dalam proses perkembangan dan proses belajar (Martini Jamaris, 2014:113). Klasifikasi tunarungu dibagi menjadi dua yaitu kurang dengar dan tuli (Asep Supena, 2015:40). 
IPA penting untuk dipelajari siswa tunarungu karena karena menyangkut tentang kehidupan sehari-hari yang dialaminya seperti proses pertumbuhan dan perkembangan, sistematis dalam berpikir dan bertindak, serta mengetahui asal-usul kehidupan. Pendekatan pembelajarannya bisa dilakukan melalui discovery-inquiry, konstruktivisme, sains, teknologi, dan masyarakat (STM), pemecahan masalah, dan proses (Yetti Supriyati, 2016:55-70). Subjek dalam penelitian ini berfokus pada siswa tunarungu kelas V di sekolah luar biasa (SLB). Berdasarkan hasil pengamatan di SLB Negeri 4 Jakarta pada tanggal 23 Juli 2018, dalam pembelajaran IPA di kelas V khususnya pada pokok bahasan daur hidup hewan, media pembelajaran yang digunakan oleh guru masih terbatas, hanya berbentuk 2 dimensi seperti poster, foto, dan video. Hal ini yang berdampak pada beberapa aspek, diantarnya; sebagian siswa merasa bosan, daya ketertarikan belajar menjadi berkurang, banyak yang berbicara dengan temannya saat pembelajaran, serta sikap kritis dan aktif menjadi tidak terasah dengan baik. Berkaitan dengan dampak tersebut, perlu adanya penyesuaian media pembelajaran dengan karakteristik siswa tunarungu agar kegiatan belajar-mengajar dapat berjalan kondusif, efektif, dan efisien. Penyesuaian media pembelajaran diasumsikan akan lebih menarik jika ditampilkan secara visual, belum pernah digunakan sebelumnya, mudah digunakan, dan mudah diakses dimanapun tempatnya.

Penggunaan media pembelajaran sangat dibutuhkan untuk menunjang tujuan pembelajaran yang ingin dicapai. Media pembelajaran dapat membantu siswa untuk menangkap materi pelajaran yang disampaikan oleh guru (Cecep Kusnadi dan Bambang Sutjipto, 2013:6). Media pembelajaran adalah segala sesuatu yang dapat digunakan untuk menyalurkan pesan dari pengirim ke penerima sehingga dapat merangsang pikiran, perasaan, perhatian, dan minat serta perhatian siswa sedemikian rupa sehingga proses belajar terjadi (Arief Sadiman, 2014:7). Media pembelajaran meliputi buku, tape recorder, kaset, video camera, video recorder, film, slide (gambar bingkai), foto, gambar, grafik, televisi, dan komputer (Hasnida, 2014:34).

Salah satu media yang sesuai dengan karakteristik siswa tunarungu adalah hologram. Hologram merupakan media pembelajaran yang dapat memvisualisasikan suatu objek menjadi tiga dimensi (3D). Penelitian tentang hologram pernah dilakukan oleh Reshma Thange, dkk (2016) yang mengkaji tentang interactive holograms using pepper ghost pyramid di Mumbai Maharastra, India. Berdasarkan hasil penelitiannya, hologram dapat meningkatkan pemahaman dan membangun kepercayaan diri dengan mengubah informasi yang kompleks menjadi mudah dipahami, analisis yang lebih cepat, dan memudahkan dalam pengambilan keputusan. Penelitian berikutnya dilakukan oleh Erwin Januarisman dan Anik Ghufron (2016) yang mengkaji tentang pengembangan media pembelajaran berbasis web mata pelajaran ilmu pengetahuan alam untuk siswa kelas VII. Berdasarkan hasil penelitiannya, kualitas media yang dibuat sangat baik dan dapat meningkatkan hasil belajar dengan cukup signifikan. Berdasar pada penelitian yang telah dilakukan sebelumnya, peneliti berinisiatif untuk memodifikasi media hologram. Modifikasi dilakukan dengan mengonstruksi website yang didalamnya terdapat hologram. Hologram tentunya jauh lebih efisien, karena hasil dari hologram sendiri dapat dilihat secara $360^{\circ}$. Penggunaan hologram di website berbeda dengan 3D di monitor karena 3D di monitor hanya dapat dilihat di dalam monitor saja, sedangkan hologram di dalam website dapat memunculkan gambar kepermukaan dengan menggunakan alat bantu prisma yang bisa dilihat dari berbagai macam sisi. Gambar yang muncul dipermukaan ini akan disesuaikan dengan konten materi science (IPA). Modifikasi median ini diasumsikan mampu menjadi media pembelajaran yang lebih efektif mengingat pada media ini objek dan kejadian dapat divisualisasikan secara realistik menyerupai keadaan yang sebenarnya, meskipun tidak berarti bahwa media tersebut harus selalu menyerupai keadaan yang sebenarnya.

Penggunaan teknologi hologram sebagai media pembelajaran yang menggunakan teknologi 3D diasumsikan akan merangsang penggunaan otak kanan sehingga diharapkan siswa mampu mengingat materi pelajaran lebih lama dibandingkan materi yang disampaikan secara tertulis. Media pembelajaran interaktif 3D juga dapat digunakan sebagai bahan ajar bagi guru sekaligus sebagai sumber belajar bagi anak (Febiharsa dan Djuniadi, 2018). Siswa tunarungu memiliki gaya belajar visual dalam memahami pembelajaran yang disampaikan oleh guru. Hologram sebagai media yang mampu memunculkan gambar kepermukaan sehingga dapat menarik perhatian merupakan salah satu media yang sesuai dengan gaya belajar siswa tunarungu. Oleh karena itu, media pembelajaran ini diasumsikan sesuai apabila diterapkan pada siswa tunarungu dalam menunjang pembelajaran. Berdasarkan permasalahan di atas, peneliti mengembangkan media pembelajaran berupa magical 
science yang akan digunakan sebagai media pembelajaran IPA berbasis website untuk siswa tunarungu. Magical science hadir sebagai solusi alternatif dalam penyampaian materi pembelajaran IPA di kelas. Materi yang menjadi fokus penelitian adalah daur hidup hewan kupu-kupu. Media ini akan memvisualisasikan proses daur hidup kupu-kupu dimulai dari perubahan telur menjadi ulat, perubahan menjadi kepompong hingga akhirnya menjadi kupu-kupu dengan bantuan hologram.

Media magical science bagi siswa tunarungu yang dirancang sesuai pembelajaran IPA pada kurikulum 2013 kelas V tunarungu dengan kompetensi inti (KI) 3 yaitu memahami pengetahuan faktual dengan cara mengamati (melihat dan membaca), serta menanya berdasarkan rasa ingin tahu tentang dirinya, makhluk ciptaan Tuhan dan kegiatannya, dan benda-benda yang dijumpainya di rumah dan di sekolah. Kompetensi dasar (KD) 3.2 yaitu mendeskripsikan daur hidup beberapa jenis hewan. Kompetensi inti (KI) 4 yaitu menyajikan pengetahuan faktual dalam bahasa yang jelas dan logis, dalam karya yang estetis; dalam gerakan yang mencerminkan anak sehat; dan dalam tindakan yang mencerminkan perilaku anak beriman dan berakhlak mulia. Kompetensi dasar (KD) 4.2 yaitu menceritakan tahapan daur hidup beberapa jenis hewan. Media yang dirancang harus mampu menstimulus siswa untuk aktif dalam belajar.

\section{METODE}

Penelitian ini bertujuan untuk menghasilkan produk berupa media pembelajaran IPA berbasis website yang dapat memvisualisasikan daur hidup hewan kupu-kupu. Penelitian ini dilaksanakan di kelas V SLB Negeri 4 Jakarta. Penelitian ini menggunakan metode research and development (RnD) dengan model pengembangan Sugiyono. Penelitian ini dilaksanakan kurang lebih tiga bulan yang dimulai dari bulan Oktober sampai bulan Desember tahun 2019.

Penelitian pengembangan ini dilaksanakan melalui tujuh tahapan yang telah dikerucutkan dari sepuluh tahapan penelitian berdasarkan metode $\mathrm{RnD}$ dengan model pengembangan Sugiyono. Adapun tahapan yang dilalui yaitu, menemukan potensi dan masalah, pengumpulan data, desain produk, validasi desain, revisi desain, uji coba produk, dan tahap terakhir yaitu revisi produk. Pada tahap pertama, peneliti melakukan asesmen guna mengetahui potensi yang dimiliki oleh siswa tunarungu dengan kemampuan visualnya. Tahap kedua, peneliti melakukan pengamatan terhadap proses kegiatan pembelajaran di kelas V tunarungu SLB Negeri 4 Jakarta dalam mata pelajaran IPA mengenai daur hidup hewan kupu-kupu. Selain observasi, pengumpulan data juga dilakukan melalui tahap wawancara ddengan guru kelas terkait proses dan hasil belajar siswa dalam mengerjakan soal yang diberikan. Tidak hanya itu, peneliti juga berdiskusi dengan guru kelas mengenai media pembelajaran yang telah digunakan, serta karakteristik siswa saat pembelajaran sedang berlangsung. Tahap ketiga yaitu desain produk. Desain produk Magical Science yang dirancang berupa sebuah website dengan beberapa fitur didalamnya seperti fitur materi, soal, cara penggunaan, dan about. Hasil final desain produk kemudian divalidasi oleh ahli pada tahap keempat. Setelah mendapatkan penilaian dari ahli makan dilakukan perbaikan desain produk sesuai saran yang diberikan. Uji coba produk dilakukan setelah media selesai diperbaiki berdasarkan saran dari ahli. Uji coba produk dilakukan di kelas V SLB Negeri 4 Jakarta dengan subjek siswa tunarungu. Hasil ujicoba dijadikan dasar untuk melakukan revisi produk kembali di akhir tahap penelitian.

Teknik analisis data penelitian menggunakan teknik yaitu expert review terkait produk yang dikembangkan dengan expert dosen teknologi pendidikan dan guru kelas SLBN 4 Jakarta. Teknik kedua yaitu field test. Teknik ini digunakan untuk pengamatan, pre test, dan post test pada siswa.

\section{HASIL DAN PEMBAHASAN}

Nama produk dari hasil pengembangan karya inovasi ini adalah "magical science". Media magical science ini dibuat dan dikembangkan untuk memvisualisasikan daur hidup hewan kupu-kupu pada siswa tunarungu. Media ini berbasis website yang terdiri dari beberapa fitur. Fitur pertama adalah fitur materi. Fitur ini berisikan naskah tentang daur ulang hidup hewan kupu-kupu. Bahasa yang digunakan dalam fitur ini telah disesuaikan dengan kondisi siswa agar mudah dipahami. Di dalam fitur materi juga disajikan hologram daur hidup hewan kupu-kupu yang bisa diakses oleh pengguna melalui laptop, komputer, dan android. Fitur kedua adalah fitur soal. Fitur ini menyajikan kumpulan soal dari materi yang ada untuk mengetahui sejauh mana pemahaman siswa terhadap materi. Ketiga, fitur cara penggunaan yang menampilkan tata cara penggunaan aplikasi magical science. Keempat, fitur about 
yang menyajikan informasi tentang magical science beserta kontak yang dapat dihubungi. Media magical science ini juga dilengkapi dengan bangun ruang prisma segi empat yang dapat membuat gambar dan video menjadi 3D untuk memvisualisasikan daur hidup hewan kupu-kupu jika prisma tersebut diletakkan diatas gambar dan video melalui komputer, laptop, maupun handphone. Adapun spesifikasi produk magical science adalah sebagai berikut:

1. Website magical science

Website Address : : www.deventri.com/masas

Domain : Deventri.com

Hosting : Niaga Hoster

Teknologi pendukung : HTML, CSS, Bootstrap, Font Awesome, PHP,

2. Bangun ruang prisma segi empat untuk notebook

$\begin{array}{ll}\text { Ukuran } & : 3 \mathrm{~cm} \times 15 \mathrm{~cm} \text { x } 21 \mathrm{~cm} \\ \text { Bahan } & : \text { Akrilik } \\ \text { Warna } & : \text { Bening }\end{array}$

3. Bangun ruang prisma segi empat untuk handphone

$\begin{array}{ll}\text { Ukuran } & : 1 \mathrm{~cm} \times 3,5 \mathrm{~cm} \times 6 \mathrm{~cm} \\ \text { Bahan } & : \text { Akrilik } \\ \text { Warna } & : \text { Bening }\end{array}$

Kelebihan produk magical science :

a. Media magical science ini dapat dijadikan media pembelajaran yang digunakan untuk memvisualisasikan daur hidup hewan kupu-kupu pada siswa tunarungu kelas $\mathrm{V}$.

b. Media magical science ini mempermudah siswa tunarungu untuk mengamati proses daur hidup hewan kupu-kupu dalam waktu yang singkat.

c. Media magical science ini mempermudah siswa untuk memahami materi pembelajaran ipa dengan bahasa yang sederhana dan mudah dimengerti.

d. Media magical science ini dapat meningkatkan hasil belajar siswa pada pembelajaran IPA.

e. Media magical science ini dilengkapi dengan cara penggunaan agar siswa tunarungu dapat mempelajarinya secara mandiri.

f. Media magical science ini mudah diakses dan dibawa kemana saja hanya dengan menggunakan handphone, laptop, dan komputer yang terkoneksikan internet melalui www.deventri.com/masas

g. Bangun ruang prisma segi empat pada media magical science ini menggunakan kaca yang aman dan tidak mudah pecah karena dibuat dari akrilik.

Kelemahan produk magical science:

a. Media magical science ini hanya dapat diakses melalui internet dalam kondisi online. jika tidak, maka media magical science tidak dapat digunakan.

b. Penggunaan kaca akrilik yang mudah tergores dapat menampilkan video hologram 3D kurang bagus.

c. Video hologram 3D pada media magical science dapat optimal jika pencahayaan ruangan dalam kondisi redup. Jika tidak, maka video yang dihasilkan kurang bagus.

Cara penggunaan produk magical science

Media magical science ini dikembangkan sebagai salah satu media pembelajaran untuk siswa tunarungu kelas V. Media ini dibuat dengan tujuan untuk memvisualisasikan daur hidup hewan kupukupu. Sebelum memulai kegiatan pembelajaran, siswa diminta untuk membawa handphone atau laptop yang sudah terkoneksi online melalui internet. Selanjutnya, siswa dijelaskan mengenai cara penggunaan media magical science. Setelah siswa mengerti, siswa dapat mencoba mengggunakan media magical science.

Berikut ini langkah-langkah penggunaan media magical science secara terperinci :

a. Siapkan handphone atau laptop yang sudah terkoneksi dengan internet.

b. Siswa diminta untuk membuka browser dengan memasukkan alamat website www.deventri.com/masas.

c. Setelah masuk ke dalam alamat website, halaman utama dari magical science akan tampil. Terdapat empat fitur yang dapat diakses oleh siswa yaitu materi, soal, cara penggunaan, dan about. 
d. Jika siswa mengakses fitur materi, maka akan memperoleh bahan-bahan pembelajaran khususnya mengenai daur hidup hewan kupu-kupu. Di dalam fitur materi juga terdapat video hologram 3D yang bisa digunakan dengan meletakkan bangun ruang prisma segi emat di atas handphone ataupun laptop.

e. Jika siswa mengakses fitur soal, maka akan disajikan kumpulan soal yang diakhiri dengan perolehan skor dari jawaban yang telah dipilih. Fitur soal ini dapat mengukur tingkat keberhasilan siswa dalam memahami pembelajaran IPA.

f. Jika siswa mengakses fitur cara penggunaan, maka akan disajikan petunjuk cara penggunaan media magical science.

g. Jika siswa mengakses fitur about, maka akan disajikan informasi untuk memberikan saran dan masukan pada media magical science.

Ada tujuh tahapan yang telah dilakukan oleh peneliti dalam melakukan penelitian ini. Pertama, menemukan potensi dan masalah. Peneliti menemukan potensi yang dimiliki oleh siswa tunarungu dengan kemampuan visualnya. Siswa tunarungu sangat tertarik dengan pembelajaran yang bersifat visual. Apalagi visual yang ditampilkan itu unik dan belum pernah dilihat sebelumnya. Namun, masalah ditemukan oleh peneliti saat di sekolah adalah media pembelajaran yang masih terbatas. Siswa hanya disajikan media pembelajaran 2D berupa foto dan poster. Hal ini yang menyebabkan sebagian siswa merasa bosan, daya ketertarikan belajar menjadi berkurang, banyak yang berbicara dengan temannya saat pembelajaran, sikap kritis, dan aktif menjadi tidak terasah dengan baik.

Kedua, pengumpulan data. Dari pengamatan terhadap proses kegiatan pembelajaran di kelas V tunarungu SLB Negeri 4 Jakarta dalam mata pelajaran IPA mengenai daur hidup hewan Kupu-kupu. Lalu, kemudian dari hasil wawancara dengan guru kelas mengenai proses dan hasil belajar siswa dalam mengerjakan soal yang diberikan oleh guru. Lalu dilanjutkan dengan berdiskusi kepada guru kelas mengenai media pembelajaran yang telah digunakan, serta karakteristik siswa saat pembelajaran sedang berlangsung. Maka ditemukan bahwa selama ini media pembelajaran yang digunakan dalam pembelajaran IPA adalah foto dan poster. Berdasarkan hasil pengamatan yang dilakukan, menurut siswa media pembelajaran yang digunakan masih kurang menarik. Maka dari itu, peneliti melakukan pengembangan media pembelajaran yang bersifat visualistik dan menarik bagi siswa dengan sebuah website yang mudah diakses kapan dan dimana saja, serta dapat memvisualisasikan daur hidup hewan Kupu-kupu melalui hologram 3D.

Ketiga, desain produk. Peneliti mendesain produk magical science berupa sebuah website dengan beberapa fitur didalamnya seperti fitur materi, soal, cara penggunaan, dan about. Pada fitur materi, bahasa yang digunakan harus sederhana dan mudah dimengerti oleh siswa tunarungu. Selain itu, fitur materi juga dilengkapi dengan video hologram 3D mengenai daur hidup hewan kupu-kupu yang dibantu dengan bangun ruang prisma segi empat. Fitur soal berisikan kumpulan pertanyaan dari materi yang telah disajikan. Setelah siswa mengerjakan soal, maka akan keluar skor dari perolehan jawaban yang benar. Fitur cara penggunaan yang memberikan petunjuk bagi siswa untuk mengakses media. Fitur about yang memberikan informasi seputar aplikasi, siswa juga dapat memberikan saran dan masukan terhadap media magical science. 
J PK (J urnal Pendidikan Khusus), 16 (1), 2020 - 40

Indina Tarjiah, Erfan Kumiawan, Riana Bagaskorowati

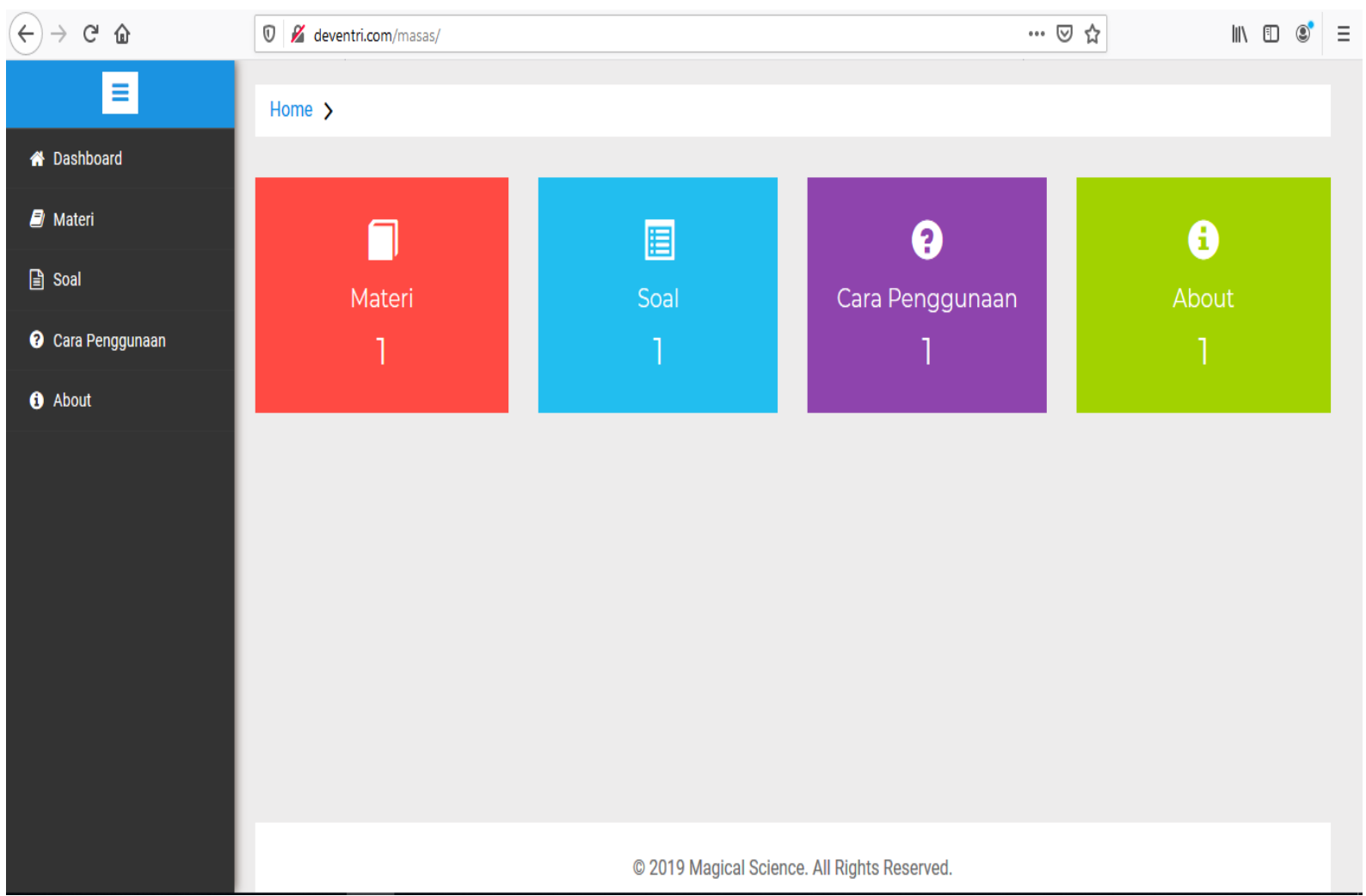

Gambar 1. Desain Produk Magical Science

Keempat, validasi desain. Validasi desain merupakan proses kegiatan untuk menilai sudah sesuaikah media pembelajaran yang telah dirancang dengan karakteristik siswa tunarungu. Peneliti menghadirkan beberapa ahli yang telah berpengalaman untuk melakukan penilaian terhadap produk baru yang telah dirancang tersebut, seperti bapak Cecep Kurstardi sebagai ahli media, ibu Dahliani sebagai ahli materi, serta ibu Miranti Nurliandra sebagai ahli tunarungu. Setelah validasi desain, peneliti dapat menemukan kelebihan dan kelemahan dari desain yang telah dibuat. Berikut adalah hasil validasi desain dari para ahli :

Tabel 1. Hasil Rekapitulasi Uji Coba Ahli

\begin{tabular}{ccc}
\hline Responden & Nilai Rata-rata & Keterangan \\
\hline Ahli Media & 3,65 & Baik \\
Ahli Materi & 3,25 & Baik \\
Ahli Tunarungu & 3,20 & Baik \\
Rata-rata Keseluruhan & 3,36 & Baik \\
\hline
\end{tabular}

Skala yang digunakan dalam instrumen ini adalah 1 -4, dengan kriteria sebagai berikut :

$\begin{array}{ll}4 & =\text { Sangat Baik } \\ 3-3,9 & =\text { Baik } \\ 2-2,9 & =\text { Cukup Baik } \\ 1-1,9 & =\text { Kurang Baik }\end{array}$

Hasil rekapitulasi uji coba ahli terhadap media Magical Science, maka hasil rata-rata keseluruhan yang telah dicapai adalah baik, yaitu dengan nilai 3,36. Berdasarkan masukan dari para ahli dapat disimpulkan bahwa media magical science ini masih perlu diperbaiki.

Kelima, revisi desain. peneliti diberikan kesempatan untuk memperbaiki desain yang telah dibuat atas dasar masukan dari para ahli melalui kuisioner dan diskusi. Berikut ini revisi desain yang telah dilakukan oleh peneliti: 
J PK (J urnal Pendidikan Khusus), 16 (1), 2020 - 41

Indina Tarjiah, Erfan Kumiawan, Riana Bagaskorowati

Tabel 2. Saran dari Para Ahli

\begin{tabular}{ll}
\hline Responden Ahli & Saran dan Komentar \\
\hline Ahli Media & Tambahkan tujuan pembelajaran. \\
(Cecep Kurstardi, M.Pd.) & Tambahkan lembar kerja (satu soal essay). \\
& Mengubah Kupu-kupu pada video hologram 3D menjadi lebih \\
& hidup lagi. \\
Ahli Materi & Materi lebih diperjelas lagi. \\
(Dahliani, S.Pd.) & Dibagian soal lebih diperbanyak dengan menggunakan \\
& gambar. \\
Ahli Tunarungu & Media hologram kurang besar untuk digunakan secara klasikal. \\
(Miranti Nurliandra, S.Pd.) & Lebih diperhatikan lagi urutan dalam proses daur hidup hewan \\
& Kupu-kupu. \\
& Diakhir materi diberi kesimpulan secara umum. \\
\hline
\end{tabular}

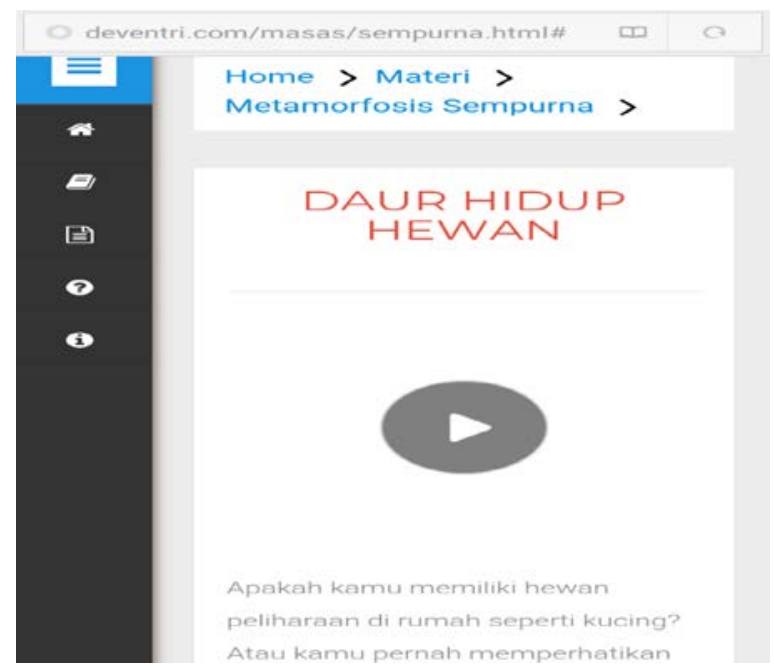

Belum ada tujuan pembelajaran diawal materi (Sebelum)

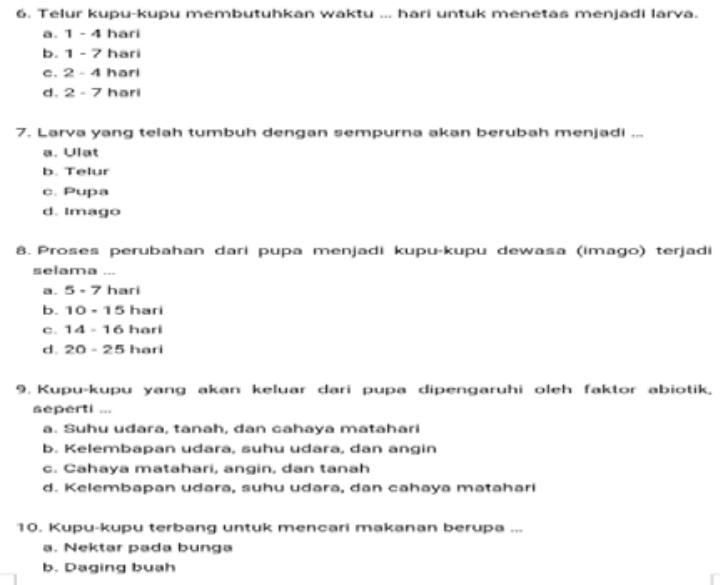

Belum ada soal essay pada lembar kerja siswa (Sebelum)

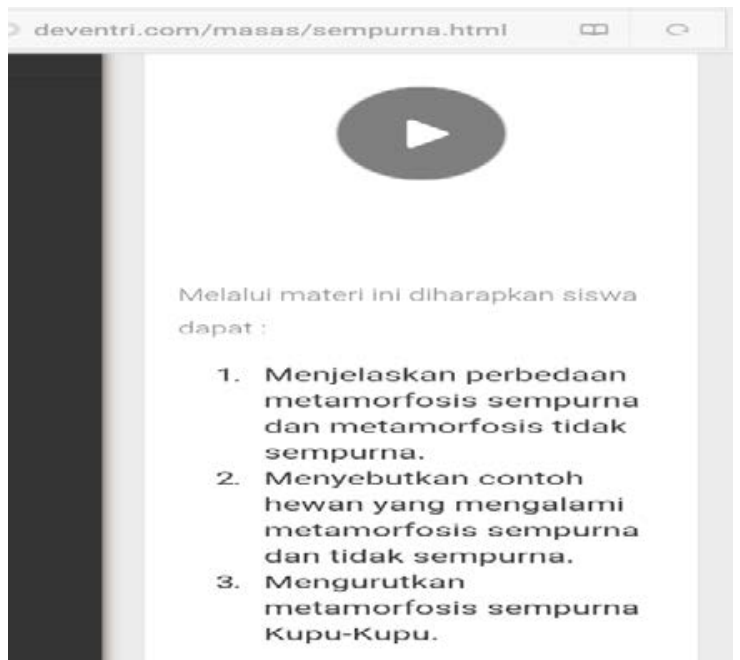

Sudah ada tujuan pembelajaran diawal materi (Sesudah)

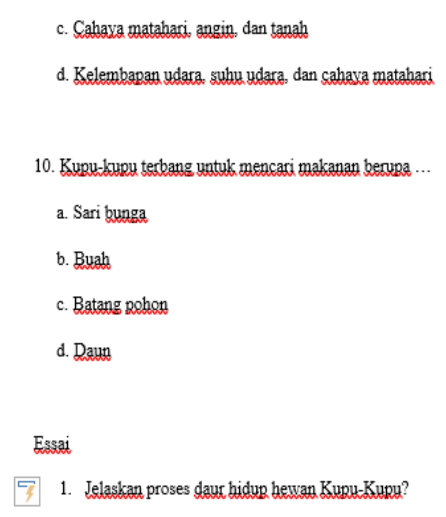

Sudah ada soal essay pada lembar kerja siswa (Sesudah) 
J PK (J urnal Pendidikan Khusus), 16 (1), 2020 - 42

Indina Tarjiah, Erfan Kumiawan, Riana Bagaskorowati

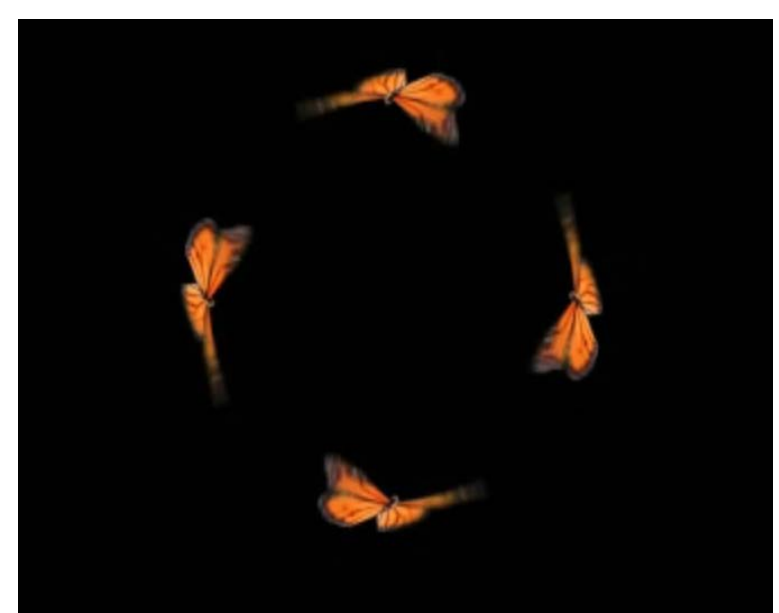

Gambar Kupu-kupu pada video hologram 3D

(Sebelum)

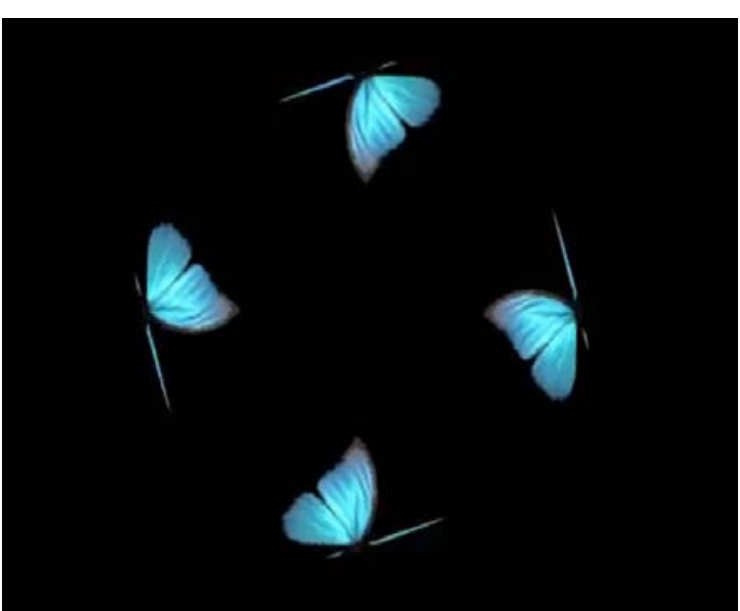

Gambar Kupu-kupu pada video hologram 3D menjadi lebih hidup (Sesudah)

Gambar 2. Revisi dari ahli media

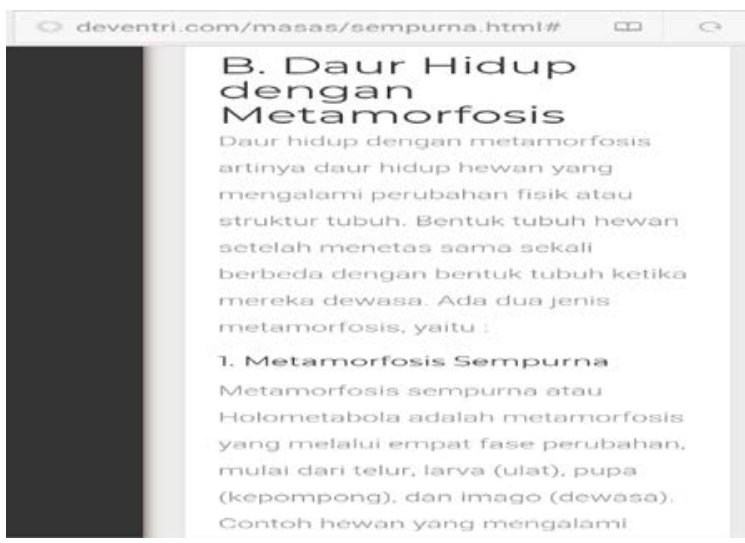

Belum sederhana konten materi (sebelum)

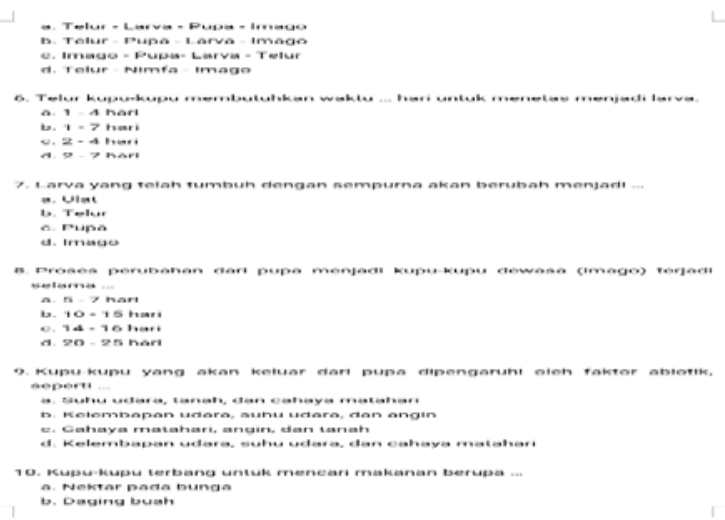

Belum ada gambar pada soal (Sebelum)

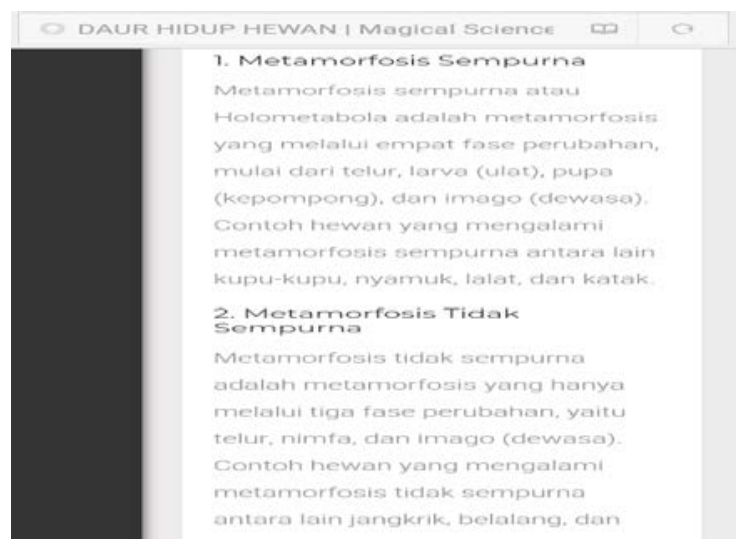

Sudah sederhana konten materi (Sesudah)

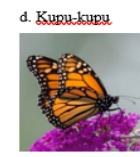

4. Contoh hewxan yang memiliki metamertosis tidak sempuspa adalah .

a. Kupu-bupu

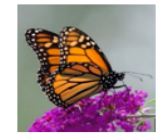

b. Janglcrik

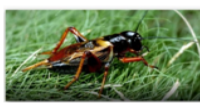

Sudah ada gambar pada soal (Sesudah)

Gambar 3. Revisi dari ahli materi 
J PK (J urnal Pendidikan Khusus), 16 (1), 2020 - 43

Indina Tarjiah, Erfan Kumiawan, Riana Bagaskorowati

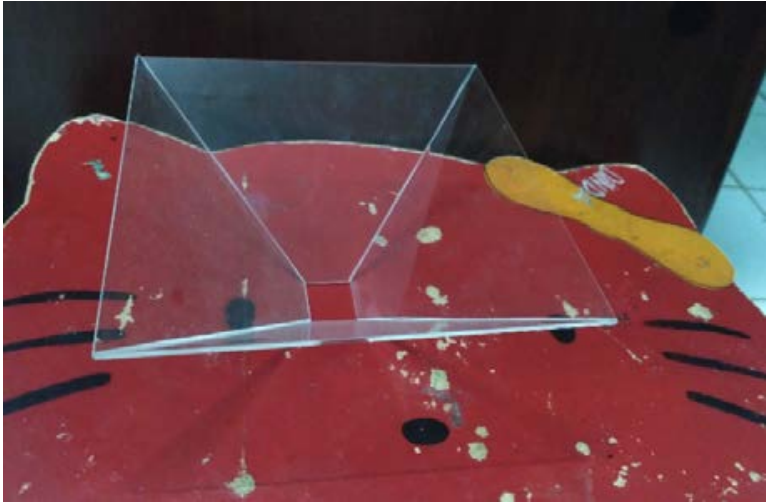

Ukuran prisma masih kurang besar

(Sebelum)

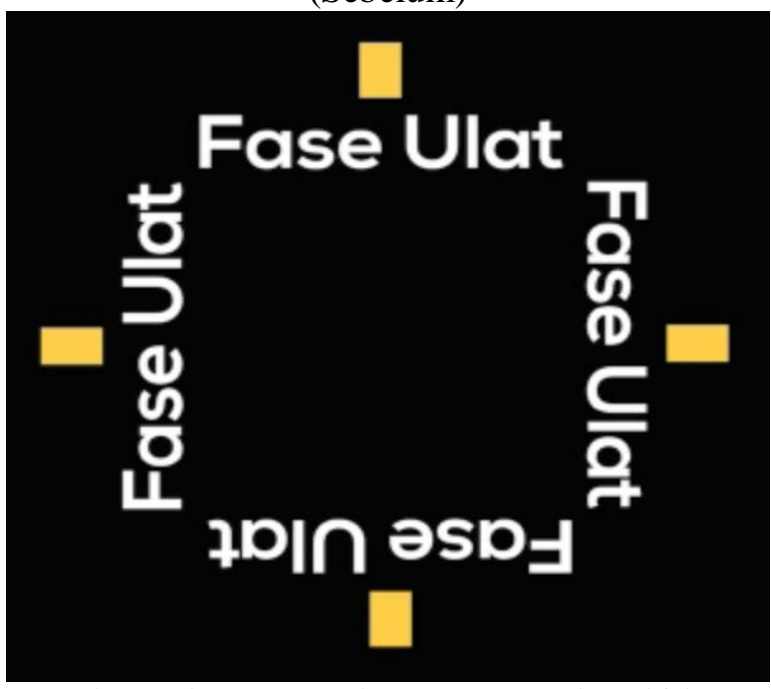

Belum ada urutan tahapan proses daur hidup hewan Kupu-kupu

(Sebelum)

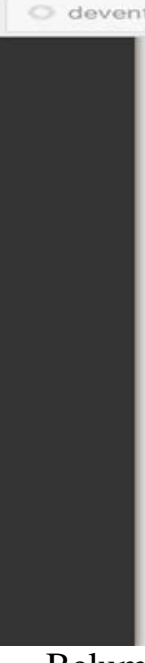

Belum ada kesimpulan materi secara umum

(Sebelum)

Gambar 4. Revisi dari ahli tunarungu

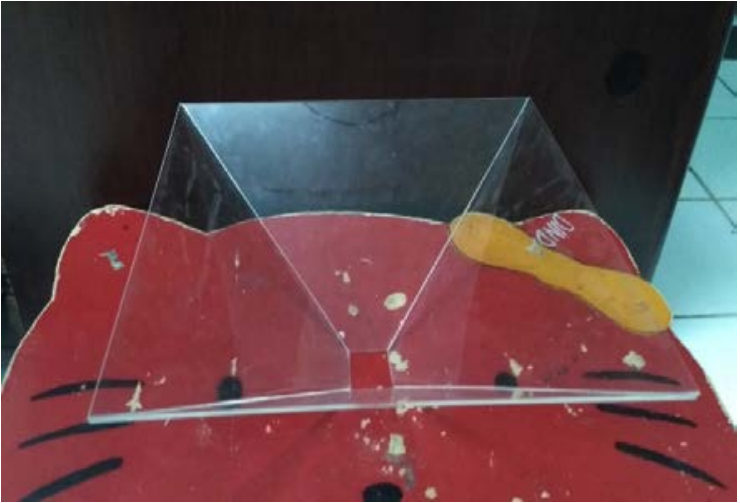

Ukuran prisma yang sudah diperbesar (Sesudah)

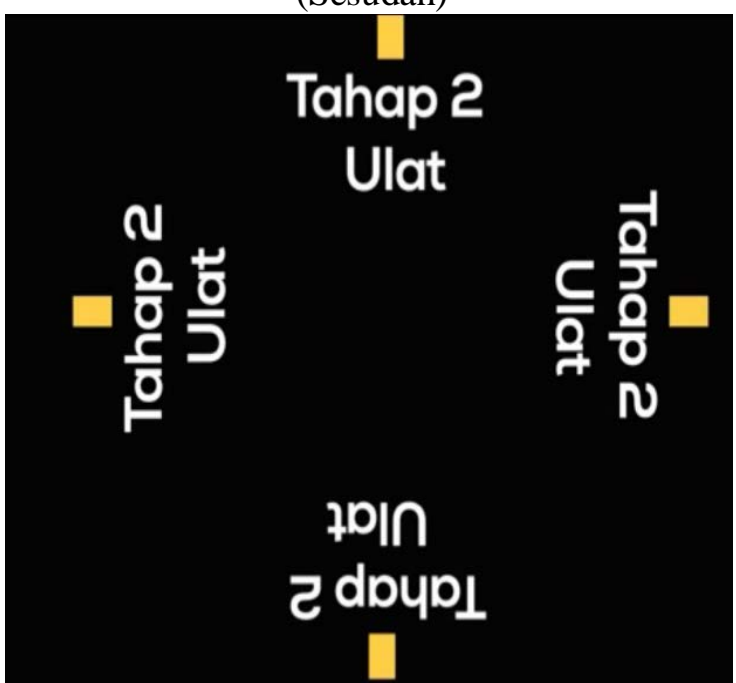

Sudah ada urutan tahapan proses daur hidup hewan Kupu-kupu

(Sesudah)

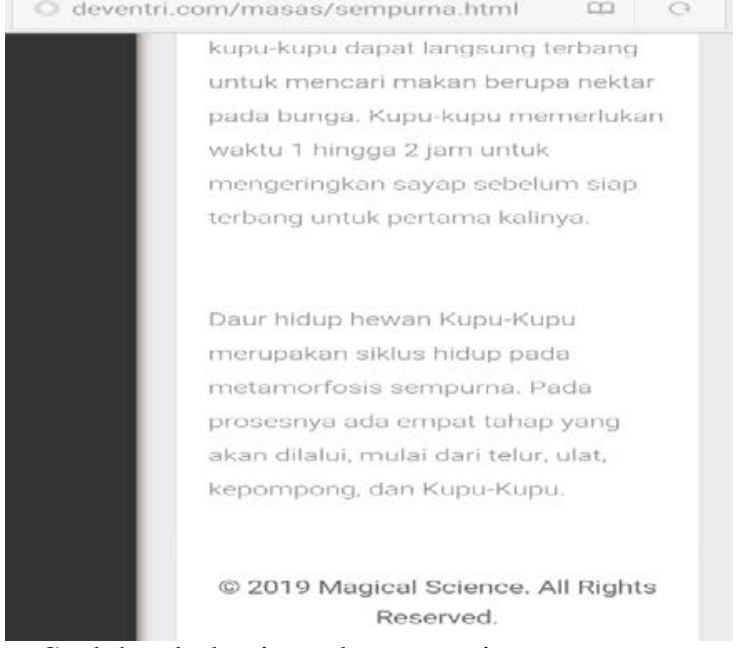

Sudah ada kesimpulan materi secara umum (Sesudah)

Keenam, uji coba produk yang diterapkan pada siswa tunarungu kelas V di SLB Negeri 4 Jakarta. Terdapat enam siswa tunarungu yang melakukan uji coba terhadap media magical science. Uji coba yang dilakukan dengan melakukan pengamatan, pre test, dan post test. Berikut ini hasil uji coba yang telah dilakukan: 
Tabel 3. Hasil Pengamatan

\begin{tabular}{cl}
\hline No. & \multicolumn{1}{c}{ Soal Pengamatan } \\
\hline 1. & $\begin{array}{l}\text { Siswa tunarungu dapat } \\
\text { menggunakan handphon } \\
\text { atau laptop. }\end{array}$ \\
2. & $\begin{array}{l}\text { Siswa tunarungu dapat } \\
\text { mengakses website } \\
\text { magical science. }\end{array}$
\end{tabular}

3. Siswa tunarungu dapat membuat bangun ruang prisma segi empat dari plastik transparan.

4. Kemudahan dalam menggunakan bangun ruang prisma segi empat terhadap video magical science untuk memvisualisasikan daur hidup hewan Kupu-kupu.

5. Kemudahan dalam mengakses seluruh fitur yang terdapat dalam website magical science.

6. Kemudahan dalam menjawab soal-soal yang terdapat dalam website magical science.

7. Media magical science dapat menghemat waktu dalam proses pembelajaran IPA khususnya mengenai daur hidup hewan Kupu-kupu.

\section{Jawaban}

Media magical science dapat digunakan diakses melalui handphone dan laptop. Sehingga jika siswa belum bisa menggunakan handphone dan laptop, maka siswa juga belum bisa menggunakan media magical Science. Dalam menggunakan handphone atau laptop, siswa sudah dapat menggunakannya dengan sangat baik. Karena dalam kesehariannya, siswa sudah menggunakan handphone untuk berkomunikasi.

Dalam mengakses website magical science, siswa tunarungu sudah dapat mengaksesnya dengan sangat baik. Karena media Magical Science dibuat untuk mempermudah siswa dalam menggunakannya. Hanya dengan mengakses www.deventri.com/masas, pada browser siswa sudah dapat mengakses website.

Jika video hologram ingin divisualisasikan dengan gambar 3D, maka harus menggunakan bangun ruang prisma segi empat dengan warna transparan. Siswa tunarungu membuat bangun ruang prisma segi empat dengan menggunakan plastic transparan. Pada awalnya, siswa mengalami kesulitan dengan melakukan pengukuran pada setiap sisinya. Guru membantu siswa untuk mempermudah pengukuran dengan menggunakan double tip agar plastik transparannya tidak bergeser. Lalu dipotong dengan menggunakan karter dan penggaris. Setelah itu, siswa sudah dapat membuatnya secara mandiri.

Bangun ruang prisma segi empat dengan warna transparan yang telah dibuat. Selanjutnya digunakan untuk memvisualisasikan daur hidup hewan kupu-kupu dalam bentuk 3D. siswa sudah dapat menggunakannya dengan sangat baik. Karena siswa hanya meletakkan bangun ruang prisma segi empat diatas handphone atau laptop. Setelah itu, video daur hidup hewan Kupu-kupu akan muncul dalam bentuk 3D.

Fitur yang terdapat dalam website magical science yaitu fitur materi, soal, cara penggunaan, dan about. Siswa tunarungu dapat mengakses seluruh fitur tersebut dengan baik. Hanya dengan mengklik salah fitur yang diinginkan, sudah dapat mengakses fitur tersebut. Jika siswa masih ada yang belum mengerti untuk mengakses seluruh difitur yang ada. Siswa dapat mempelajarinya terlebih dahulu difitur cara penggunaan.

Dalam mengukur siswa sudah atau belum dalam memahami materi yang terdapat pada media magical science. Maka diperlukan tes dalam bentuk soal untuk mengukurnya. Ada 10 soal yang dapat dijawab oleh siswa. Siswa mudah dalam menjawab soal-soal yang terdapat pada fitur soal. Hanya dengan mengklik salah satu jawaban dari pilihan yang telah diberikan hingga 10 soal telah dijawab. Siswa langsung mengetahui skor yang diperoleh.

Pada proses pembelajaran, media magical science dapat menghemat waktu. Guru dapat menjelaskan materi secara singkat. Siswa juga bisa belajar mandiri dengan mengaksesnya melalui website. Serta proses daur hidup hewan kupu-kupu, siswa tidak perlu mengamatinya selama berhari-hari. Cukup dalam beberapa menit saja, siswa dapat mengamatinya melalui video dalam bentuk 3D. 


\begin{tabular}{|c|c|c|}
\hline No. & Soal Pengamatan & Jawaban \\
\hline 8. & $\begin{array}{l}\text { Media magical science } \\
\text { dapat memotivasi siswa } \\
\text { tunarungu dalambelajar. }\end{array}$ & $\begin{array}{l}\text { Media magical science telah memotivasi siswa dalam proses } \\
\text { pembelajaran. karena medianya yang menarik untuk digunakan, } \\
\text { belum pernah dilihat dan digunakan sebelumnya. Bahkan, dapat } \\
\text { memvisualisasikan gambarnya dalam bentuk 3D. }\end{array}$ \\
\hline 9. & $\begin{array}{l}\text { Keterbacaan media } \\
\text { magical science dalam } \\
\text { tulisan. }\end{array}$ & $\begin{array}{l}\text { Tulisan media magical science dapat dilihat fleksibel oleh siswa } \\
\text { tunarungu dengan baik. karena tulisannya dapat diperbesar atau } \\
\text { diperkecil sesuai dengan keinginannya. }\end{array}$ \\
\hline 10. & $\begin{array}{l}\text { Kepraktisan merapikan } \\
\text { dan membawa media } \\
\text { magical science }\end{array}$ & $\begin{array}{l}\text { Media magical science ini cukup praktis dibawa kemana-mana. } \\
\text { Hanya dengan membawa handphone disertai internet. Akan } \\
\text { tetapi, dalam memvisualisasikan daur hidup hewan kupu-kupu. } \\
\text { Siswa harus membawa bangun ruang prisma segi empat. Jika } \\
\text { terbuat dari plastik transparan, maka mudah dibawa kemana- } \\
\text { mana. Jika terbuat dari akrilik, maka harus hati-hati dalam } \\
\text { membawanya. }\end{array}$ \\
\hline 11. & $\begin{array}{l}\text { Kualitas media magical } \\
\text { science. }\end{array}$ & $\begin{array}{l}\text { Media magical science kualitasnya sudah baik. Hal ini bisa } \\
\text { dilihat dari antusias siswa tunarungu dalam menggunakannya } \\
\text { saat pembelajaran. Serta hasil uji coba antara pre test dan post } \\
\text { test. }\end{array}$ \\
\hline
\end{tabular}

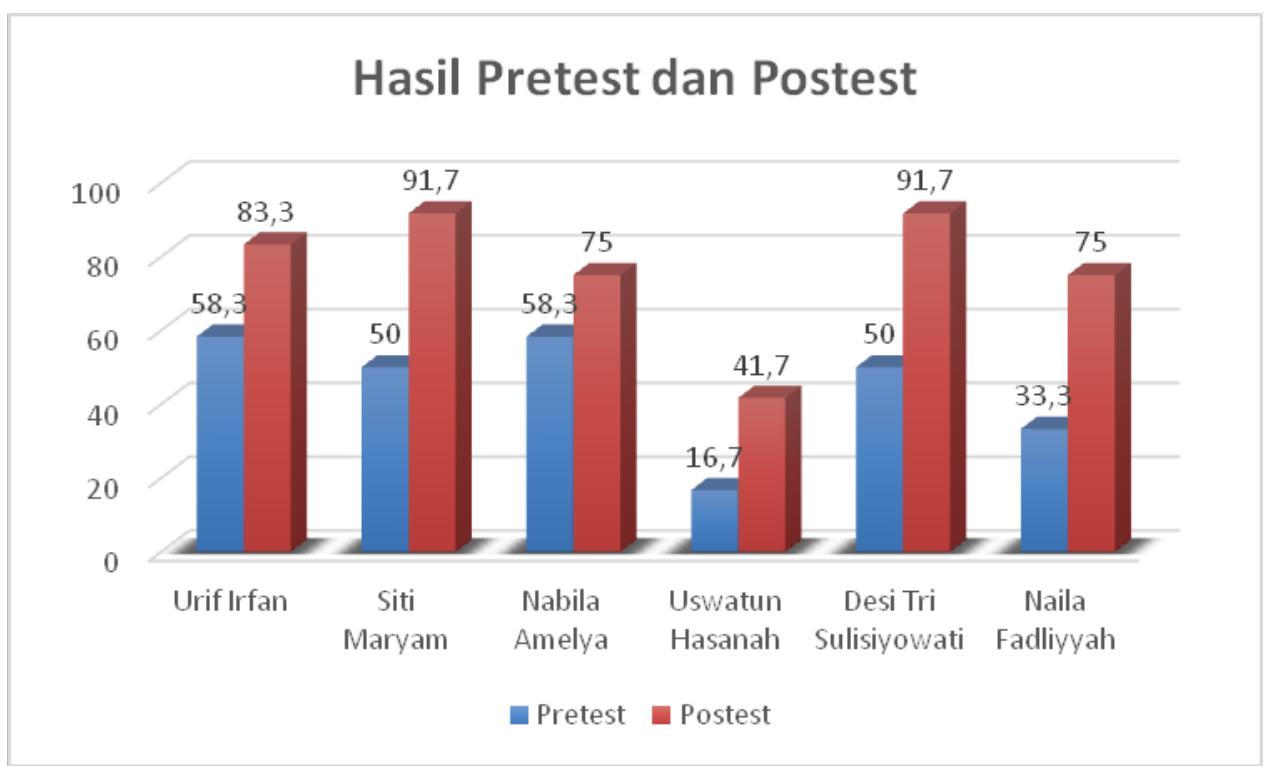

Gambar 5. Hasil Pretest dan Postest

Berdasarkan hasil pengamatan, pre test, dan post test yang dilakukan kepada enam siswa tunarungu di SLB Negeri 4 Jakarta dapat disimpulkan bahwa media magical science ini dapat dijadikan sebagai salah satu media yang dapat memotivasi belajar siswa. Hal ini dapat dilihat dari antusias dan kesenangan siswa dalam menggunakan media magical science. Materi yang disampaikan oleh guru dapat dimengerti dengan mudah dan cepat. Siswa juga bisa belajar secara mandiri dengan menggunakan media magical science. Bahkan siswa juga langsung mempraktikannya dengan membuat bangun ruang prisma segi empat untuk memvisualisasikan daur hidup hewan kupu-kupu dalam bentuk 3D. Setelah pengamatan, pre test, dan post test yang dilakukan. Peneliti menemukan kelemahan pada media magical science ini yaitu, website hanya bisa diakses dalam kondisi online, bangun ruang prisma yang terbuat dari akrilik harus hati-hati dalam membawanya karena mudah rusak. Berdasarkan hasil tersebut, peneliti melakukan revisi dengan menambahkan bangun ruang prisma segi empat yang terbuat dari plastik transparan sehingga mudah dibawa kemana-mana. 
Ketujuh, revisi produk. Revisi produk diperlukan mengingat masih ada siswa yang mengalami kesulitan dalam memahami materi yang terdapat pada media magical science. Hambatan yang ditemukan terdapat pada penyusunan kalimat pada materi dimana bahasa yang digunakan masih sulit dipahami oleh siswa. Oleh karena itu, dilakukan perbaikan dengan menyederhanakan kembali bahasa yang digunakan

\section{SIMPULAN}

Produk media yang dihasilkan dalam penelitian ini adalah Magical Science yang diperuntukan bagi siswa tunarungu untuk memvisualisasikan daur hidup hewan kupu-kupu. Pengembangan produk media magical science ini menggunakan metode research and development $(\mathrm{RnD})$ dengan model Sugiyono. Ada tujuh tahap yang dilakukan oleh peneliti yaitu menemukan potensi dan masalah, pengumpulan data, desain produk, validasi desain, revisi desain, dan uji coba produk. Pada proses validasi desain, peneliti menggunakan tiga ahli untuk melakukan validasi yang terdiri dari ahli media, ahli tunarungu, dan ahli materi dengan hasil rata-rata keseluruhan yang dicapai adalah baik, yaitu dengan nilai 3,36 dari nilai maksimal 4. Selanjutnya, peneliti melakukan revisi sesuai dengan masukan dari para ahli tersebut, kemudian diujicobakan kepada siswa kelas V di SLB Negeri 4 Jakarta yang berjumlah enam orang. Sehingga memperoleh hasil bahwa media magical science dapat dimanfaatkan untuk pembelajaran IPA mengenai daur hidup hewan kupu-kupu pada siswa tunarungu.

\section{DAFTAR PUSTAKA}

Arief S. Sadiman, dkk. 2014. Media Pendidikan: Pengertian, Pengembangan, dan Pemanfaatannya. Jakarta: Raja Grafindo Persada

Asep Supena. 2015. Pengantar Pendidikan Anak Berkebutuhan Khusus. Jakarta: Lembaga Pengembangan Pendidikan UNJ

Cecep Kusnadi dan Bambang Sutjipto. 2013. Media Pembelajaran: Manual dan Digital Edisi Kedua. Bogor: Ghalia Indonesia

Dhega Febiharsa dan Djuniadi Djuniadi.2018. Pengembangan Media Pembelajaran Interaktif 3 Dimensi untuk Pembelajaran Materi Pengenalan Lingkungan Pada Anak Usia Dini di Indonesia. Journal Of Studies in Early Childhood Education Vol. 1 No.1

Erwin Januarisman dan Anik Ghufron. 2016. Pengembangan Media Pembelajaran Berbasis Web Mata Pelajaran Ilmu Pengetahuan Alam untuk Siswa Kelas VII. Jurnal Inovasi Teknologi Pendidikan UNJ. Vol.3. No.2 : 166-168

Hasnida. 2014. Media Pembelajaran Kreatif: Mendukung Pengajaran pada Anak Usia Dini. Jakarta: Luxima Metro Media

Martini Jamaris. 2014. Kesulitan Belajar: Perspektif, Asesmen, dan Penanggulangannya Bagi Anak Usia Dini dan Usia Sekolah. Bogor: Ghalia Indonesia

Maskoeri Jasin. 2008. Ilmu Alamiah Dasar. Jakarta: Rajawali Pers

Nana Djumhana. 2009. Pembelajaran Ilmu Pengetahuan Alam. Jakarta: Direktorat Jenderal Pendidikan Agama Islam Departemen Agama Republik Indonesia

Reshma Thange, dkk. 2016. Interactive Holograms using Pepper Ghost Phyramid. International Journal For Scientific Research and Development. Vol.4. Issue 01 : 2321-0613

Rochman Natawidjaya. 1996. Penelitian Bagi Guru Pendidikan Luar Biasa. Jakarta: Departemen Pendidikan dan Kebudayaan Direktorat Jenderal Pendidikan Tinggi Proyek Pendidikan Tenaga Guru

Roger Pierangelo dan George Giuliani. 2006. The Special Educator's Comprehensive Guide to 301 Diagnostic Test. USA: Jossey-Bass

Sugiyono. 2015. Metode Penelitian Pendidikan: Pendekatan Kuantitatif, Kualitatif, dan R\&D. Bandung: Alfabeta

Yetti Supriyati. 2016. Pembelajaran Sains Pendidikan Dasar. Jakarta: FMIPA UNJ 
J PK (J urnal Pendidikan Khusus), 16 (1), 2020 - 47

Indina Tarjiah, Erfan Kumiawan, Riana Bagaskorowati

\section{PROFIL SINGKAT}

Indina Tarjiah, lahir di Bandung, 28 September 1964. Menyelesaikan pendidikan sarjana (strata 1/S1) jurusan Pendidikan Luar Biasa pada tahun 1989. Pada Tahun 1995 melanjutkan studi program magister (S2) pada program studi Teknologi Pendidikan Universitas Negeri Jakarta dan selanjutnya pada tahun 2008-2011 menyelesaikan studi program doctoral (S3) pada program studi Teknologi Pendidikan Universitas Negeri Jakarta.

Sejak tahun 1990 mulai bekerja di jurusan Pendidikan Luar Biasa Fakultas Ilmu Pendidikan Universitas Negeri Jakarta sebagai dosen hingga saat ini. Pada tahun 2007-2009 menjadi ketua Laboratorium Program Studi PLB FIP UNJ. Kemudian tahun 2010-2015 menjadi sekretaris Jurusan Pendidikan Luar Biasa UNJ. Pada tahun 2015-2019 menjadi Ketua Program Studi Pendidikan Luar Biasa FIP UNJ. 